\title{
TESTING WEAK FORM EFFICIENCY ON THE CAPITAL MARKETS IN SERBIA
}

Weak-form efficient market hypothesis assumes that participants on the financial markets are not able to achieve above-average returns based on historical prices. In order to establish the presence of a weak-form market efficiency in the Serbian market, the analysis incorporates daily data of the two most prominent indices on the Belgrade Stock Exchange, BELEX 15 and BELEX LINE, since their inception until 31 December 2014. Results obtained by the analysis and testing indicate that the capital market in Serbia can not be considered sufficiently efficient, more precisely it indicates that postulates assumed by the weak-form market efficiency are not fully met. Taking into account that the capital market in Serbia is still underdeveloped, primarily because of the small volumes, turnover and types of securities which are traded on the market, as well as the fact that it is not sufficiently regulated and transparent, lack of investors is noticeable. Consequently, analysis presented in this paper indicates a weak sustainability of the efficient market hypothesis in Serbia.

Key words: Weak-form efficient market hypothesis, financial markets, Belgrade Stock Exchange, BELEX 15, BELEX LINE, Semi-strong form of efficiency, Strong form market efficiency

Jovana Kršikapa-Rašajski, M.S., Manager, Raiffeisen Bank, Belgrade, e-mail: jovanak@hotmail.com

** Prof. Siniša G. Rankov, PhD, (retired), Faculty of the Computer Sciences, “John Naisbitt” University, Belgrade, e-mail: rankovs@naisbitt.edu.rs 


\section{Preliminary considerations}

The concept of market efficiency is one of the most important areas of finance and it is considered to be one of the foundations of modern financial theory. First of all, the term market efficiency is used to explain the degree of incorporation of relevant information in the price of financial instrument. Accordingly, it tries to answer the question whether it is possible to predict the future returns of securities. ${ }^{1}$ In 1970, Fama first introduced the theory of efficient market hypothesis and have since done numerous empirical studies on this subject with the aim of determining the validity of this concept.

The theory of efficient market hypothesis relies on the fact that the prices of securities on capital markets move randomly around their values and that they reflect the latest available information. ${ }^{2}$ Consequently, the underlying theory is trying to prove that on the efficient markets, investment strategies which are based on the relevant information, cannot consistently deliver positive or above average returns in the long term.

In accordance with Fama's research, efficient market hypothesis can be categorized into three levels, depending on the type of information which is used in determining the price of security:

- Weak-form market efficiency suggests that the price of financial instruments already reflect all the information related to the previous price movements, volume and turnover of securities. This form suggests that any price tracking and spotting some regularities, or irregularities on the basis of which the investor is able to predict future price movements is in fact unnecessary taking into account that prices are already established on the basis of previous price movements.

- Semi-strong form of efficiency assumes that the price of financial instruments in the market already reflects all publicly available information. Therefore, when there is a semi-strong form of market efficiency, one should turn to the collection and analysis of insider and confidential information since only on the basis of those, investor is able to achieve above average rates of returns taking into account that all available information is already included in the given price of financial instruments. It should be noted that this form of market efficiency also contains a weak-form market efficiency and consequently, analysts who are unable to achieve superior returns in markets where a weak-form of

Fama, Eugene F. and Kenneth R. French, (1988): "Permanent and Temporary Components of Stock Prices", Journal of Political Economy, 96(2): 246-273. Lo, Andrew W. and Craig A. MacKinlay, (1988): "Stock Market Prices do not Follow Random Walks: Evidence from a Simple Specification Test”, Review of Financial Studies, 1(1), 41-66.

2 Fama, Eugene F., (1970): "Efficient Capital Markets: A Review of Theory and Empirical Work”, Journal of Finance, 25(2), 383-417 
market efficiency is present, are also unable to achieve superior returns in the markets with semi-strong form of market efficiency.

- Strong form market efficiency assumes that the prices of financial instruments reflect all available information, both public and confidential, which may impact prices' formation. Therefore, it is futile to collect confidential information, as they are already included in the price of the financial instrument.

It is important to note that all the above mentioned levels of efficiency are mutually dependent. More specifically, the strong form of market efficiency assumes that the semi-strong form of market efficiency is present, while the semi-strong form of market efficiency implies that the weak-form of market efficiency is present.

Among academics there is a consensus that capital markets in developed markets such as, United States, Britain and Japan are very efficient. ${ }^{3}$ The most developed world markets are characterized by a large number of market participants who seek to take advantage of any deviation from the market price restoring it to the equilibrium. Accordingly, the efficient market hypothesis is brought in connection with the random walk hypothesis or the theory which suggests that prices randomly move around their real or intrinsic value. However, opinions on the degree of market efficiency are divided when it comes to capital markets in emerging markets. ${ }^{4}$ Also, efficient market hypothesis is less analyzed in the context of the emerging markets, whose growth in recent years has resulted in the way that they became an important part of portfolios of global financial institutions. Scientific studies indicate the existence of market inefficiencies in certain segments of the financial markets, primarily because of stock market anomalies such as unsynchronized trading, small turnovers and market shallowness which can lead to false indications of predictability of returns. It should be noted that due to the above mentioned reasons, as well as due to the lack of information, research on happening on the capital markets in the emerging countries are typically limited to testing of the weak-form market efficiency. Results of testing of the weakform market efficiency in emerging markets are somewhat more controversial compared to those on the developed markets. The existing literature which deals with the efficiency of capital markets in emerging countries is mainly oriented to South American and Asian markets, while insights about the efficiency of the European capital markets of emerging countries are scarce. While Worthington and Higgs confirm the low efficiency of 5 developed and 10 emerging countries

Chan, Kam C., Benton E. Gup and Ming-Shiun Pan(1997): "International Stock Market Efficiency and Integration: A Study of Eighteen Nations", Journal of Business Finance \& Accounting, 24(6), 803-813.

4 Bekaert, Geert i Robert J. Hodrick, (1992): "Characterizing Predictable Components in Excess Returns on Equity and Foreign Exchange Markets", Journal of Finance, 47(2), 467-509. 
based on the autocorrelation and other empirical tests, ${ }^{5}$ Claessens, Dasgupta and Glen have showed significant autocorrelation of returns of 19 emerging markets. ${ }^{6}$ Also, Gilmore and McManus rejected the hypothesis of random walk in Czech, Polish and Hungarian capital markets ${ }^{7}$ while Mateus has proven predictability of returns in the equity markets of 13 new European Union members explaining it by local information, market inefficiencies and irrationalities of investors. ${ }^{8}$

\section{Capital Market in Serbia}

Although a law on public stock exchanges was adopted by the Serbian King Milan Obrenović back in 1886, the Belgrade Stock Exchange (BSE) started operating in January1895, but it later ceased to exist in April 1941. ${ }^{9}$ With the continuation of the work of the Belgrade Stock Exchange in 1989, the formation of the Securities Exchange Commission in 1990 and the formation of Central Registry in 2002, Serbia has received institutional framework for capital market activities. Following the example of all developed countries' capital markets, in 2004 Belgrade Stock Exchange published BELEXfm index for stocks which were traded on a regulated market. The initial value was 1000 and this index represented the basic index of Belgrade Stock Exchange with the aim of describing the movement of the capital market. In October 2005, Belex15 index was released and in September 20015 it was defined and methodologically processed with an initial value of 1000. Belex 15 represents the leading index of the Belgrade Stock Exchange and it aims to define the movement of 15 most liquid stocks on the Serbian capital market. In April 2007, BELEXfm was replaced by BelexLINE index. Both indexes are used as indicators of domestic economic activity in the financial market.

As can be seen from Figure 1, the values of the indexes on the Belgrade Stock exchange have shared the fate of countries in the region regarding the impact of the global economic crisis which had started in 2007. However, these indexes did not recover as well as the countries in the region which have in turn recorded significant growths in recent years. The capital market in Serbia has not yet reached a sufficient level of development and consequently, its main fea-

Worthington, A. C. and Higgs, H. (2005):"Weak-Form Market Efficiency in Asian Emerging and Developed Equity Markets: Comparative Tests of Random Walk Behavior”, Working Paper 3, School of Accounting \& Finance, University of Wollongong

6 Claessens Stijn, Susmita Dasgupta i Jack Glen, (1995): “Return Behavior in Emerging Stock Market", The World Bank Economic Review, 9(1),131-151.

7 Gilmore, Claire G. and Ginette M. McManus(2003): "Random-Walk and Efficiency Tests of Central European Equity Markets", Managerial Finance, 29(4), 42-61.

$8 \quad$ Mateus, Tiago(2004): “The risk and predictability of equity returns of the EU accession countries”, Emerging Markets Review, 5(2), 241-266.

$9 \quad$ Belgrade Stock Exchange. Retrieved at www.belex.rs 
tures include inadequate number of market participants, lack of securities, weak liquidity, relatively expensive trading, poor transparency and insufficient degree of liberalization of capital market itself. Consequently, all of these factors imply that the market is inefficient which will be proven by this paper.

Figure 1. Values of the indices on the Belgrade Stock exchange

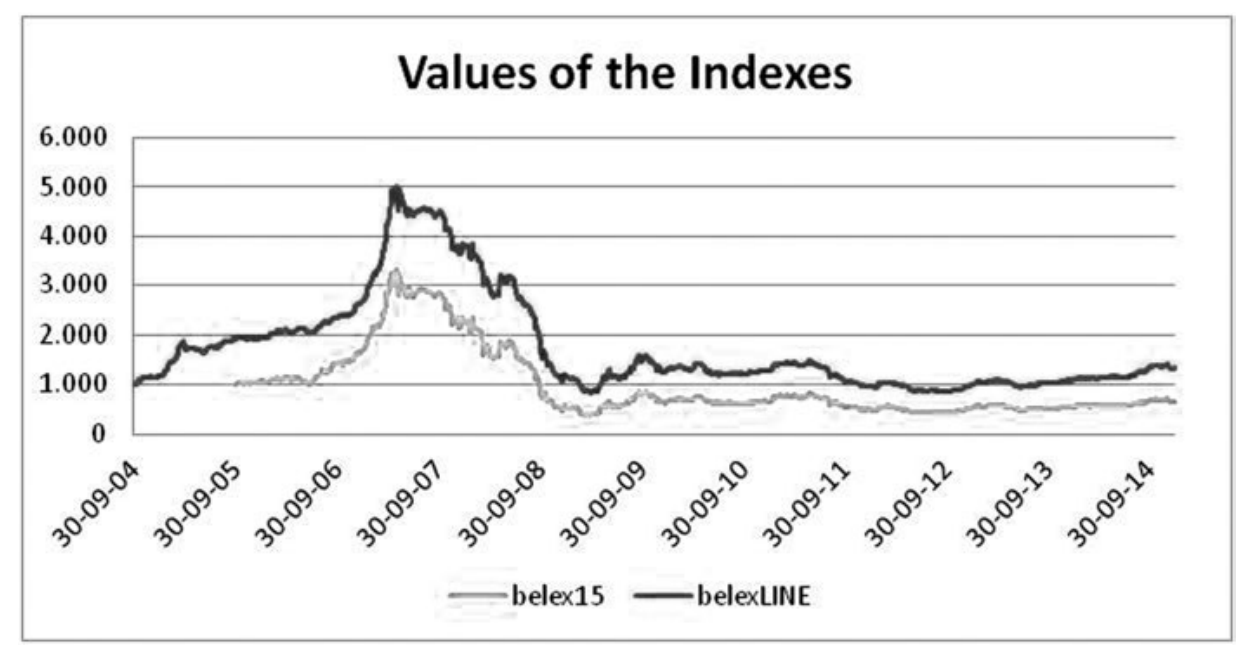

\section{Methodology}

Weak-form market efficiency implies that prices of securities follow a random walk and it assumes that residuals are normally distributed. The validity of the model and therefore its efficiency depend on the prices which can be described by a random walk model as well as by the assumption that the residuals equal returns. During testing of the weak-form market efficiency in Serbia, standard tests used for testing the random walk hypothesis include a unit root tests and autocorrelation, as well as normality tests (Working and Holbrook, $1934^{10}$ ).

Some of the normality tests used in this paper include skewness, kurtosis, Jarque Bera and graphical representation of normal probability. Skewness, as described by $S$ in the formula 1.1 represents the measure of asymmetric distribution around the mean value. If the coefficient is 0 , then we have the case of normal distribution. However, if the skewness coefficient is positive, then we have a positive asymmetry, i.e. the distribution is asymmetric to the right, while in the case of negative asymmetry, the arrangement is asymmetrical to the left. Skewness is calculated as follows:

$10 \quad$ Working Holbrook(1934):"A Random Difference Series for Use in the Analysis of Time Series", Journal of the American Statistical Association, 29(185), 11-24. 


$$
S=\frac{1}{N} \sum_{i=1}^{N}\left(\frac{y_{i}-\bar{y}}{\bar{\sigma}}\right)^{3}
$$

A complementary test used in determining the normal distribution is kurtosis. Kurtosis represents a numerical parameter which describes the extent to which a schedule is flattened compared to a normal schedule. Kurtosis has a value of 3 in the case of a normal distribution. Consequently, if the kurtosis coefficient is greater than 3 , the distribution is leptokurtic (more elongated relative to the normal schedule) while it is platykurtic if the kurtosis coefficient is less than 3 (more flattened compared to the normal schedule). The formula used for calculating the kurtosis coefficient is in conformity with the following:

$$
K=\frac{1}{N} \sum_{i=1}^{N}\left(\frac{y_{i}-\bar{y}}{\widehat{\sigma}}\right)^{4}
$$

Jarque Bera is used to determine the normal distribution in individual series. It measures the difference of skewness and kurtosis of certain series with those arising from the normal schedule. It is possible to say that significant value of JB test indicates the unstable volatility in returns of indexes. The formula used for the calculation of JB test is:

$$
J B=T \cdot \frac{S K^{2}}{6}
$$

Random walk hypothesis is consistent with the efficient market hypothesis and it reflects the financial theory that contributes to the fact that stock prices move in accordance with random walk and therefore prices cannot be predicted in advance. Random walk hypothesis implies that the next step or direction cannot be assumed on the basis of previous activities. ${ }^{11}$ When the term random walk is used on the example of the financial markets, it implies the impossibility of predicting short-term stock price changes based on previous price changes, taking into account that successive price changes of securities are independent of each other. Consequently, the random walk theory holds that the market is efficient if the current price of security incorporates all available information and therefore prices change will occur only in the case of the appearance of new information. However, if you take into account that the information is mutually unconnected and independent, then it can be concluded that the same rule applies to changes in the price of securities, i.e. that the future price movements of securities are completely unpredictable and unrelated to each other.

11 Malkiel, Burton G.(1973):A Random Walk Down Wall Street, New York, NY: W. W. Norton \& Company. 
Unit root test is test used to determine the stationarity or nonstationarity of series. Time series is considered poorly stationary when mean value, variance and covariance are independent of time and any series that is not stationary it is considered to be nonstationary. Accordingly, no stationarity indicates that the time series look like a random walk and that efficient market hypothesis can therefore be considered valid in the case of the no stationarity. Standard practice in determining the existence of a unit root is the Dickey-Fuller test, or alternatively augmented Dickey-Fuller test in which DF regression are expanded so they include lags of dependent variables in order to control for possible autocorrelation in the data.

It is important to emphasize that the existence of serial correlation implies that returns are positively correlated with the following returns, which is contrary to the hypothesis of weak form market efficiency. In order to determine the existence of correlation, correlation of residuals will be carried out and this will show autocorrelation and partial autocorrelation, as well as Ljung-Box Q's statistics for the first 30 lags.

\section{Description of sample and selection of data}

In order to reliably show the efficiency of the Serbian capital market, for the purpose of this paper, data of two existing indexes BELEX15 and BELEXline were used. Testing was conducted in the period from 4 October 2005 to 31 December 2014 for Belex15. For BelexLine data was used from 30 September 2004 until 31 December 2014. Consequently, the number of observations used in the analysis of BELEX15 and BELEXline was 2331 and 2584 respectively. Real daily values of underlying indexes were used. In order to execute the necessary statistical analysis software program Eviews 8.0 was used.

\section{Research findings and results}

Graphical representation of normal probability shown in Figure 2 allows us to get an insight into the fact that daily values of both indices are not normally distributed. Therefore, the value is not apparently independent and identically distributed, which will be later confirmed by the coefficient values of skewness and kurtosis.

As it can be seen from Table 1, coefficient of skewness is positive for Belex15, which means that mean value is larger than its median and mode. On the other hand, kurtosis is positive and more then 3 , which implies leptokurtic distribution, i.e. potentially low efficiency. 
Figure 2. Representation of probability of the Belex15 and BelexLINE indices that are not normally distributed

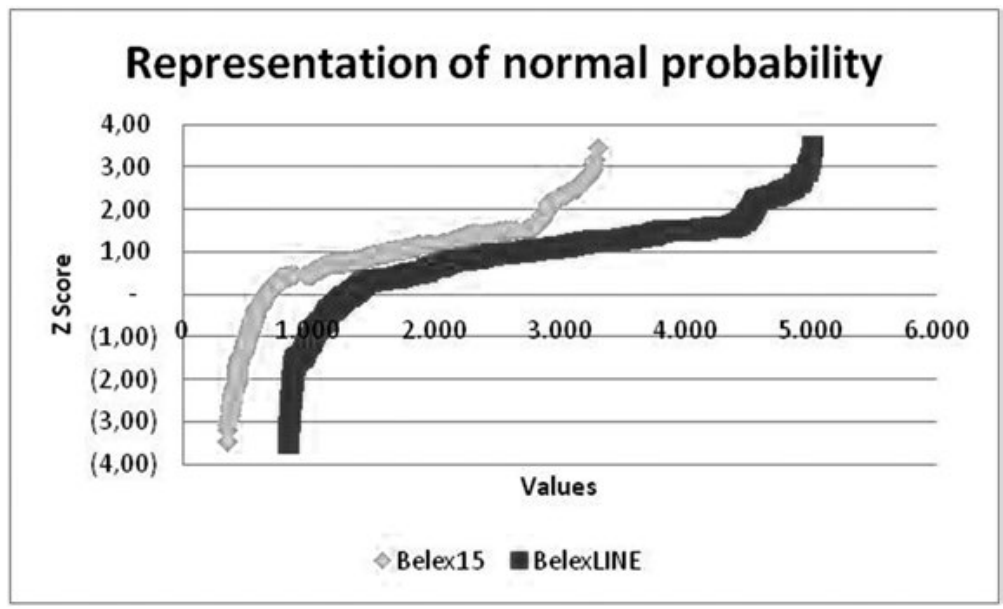

Testing was conducted in the period from 4 October 2005 to 31 December 2014 for Belex15. BelexLine data was used from 30 September 2004 until 31 December 2014.

Table 1. - Statistical parameters for BelexLINE based on daily values of index

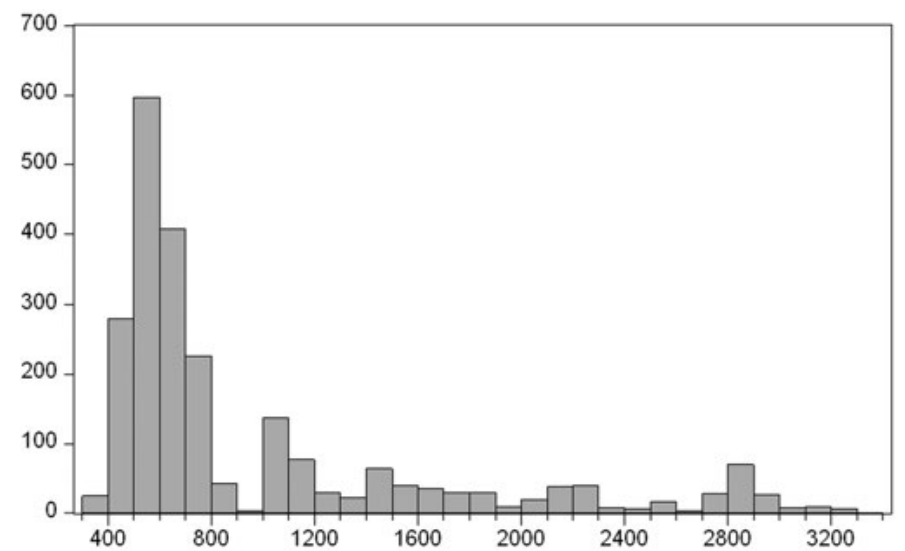

\begin{tabular}{|c|c|}
\hline $\begin{array}{l}\text { Series: BEL } \\
\text { Sample } 9 / 3 C \\
\text { Observation }\end{array}$ & $\begin{array}{l}\text { X15 } \\
2331\end{array}$ \\
\hline Mean & 983.4077 \\
\hline Median & 663.7600 \\
\hline Maximum & 3304.640 \\
\hline Minimum & 354.3900 \\
\hline Std. Dev. & 689.3000 \\
\hline Skewness & 1.671337 \\
\hline Kurtosis & 4.753015 \\
\hline Jarque-Bera & 1383.694 \\
\hline Probability & 0.000000 \\
\hline
\end{tabular}

BelexLINE statistical parameters are shown in Table 2 and they indicate that skewness and kurtosis are both positive which was also the case with Belex15 index. Moreover, kurtosis is greater than 3, which indicates that small changes in the index value are less frequent due to the fact that the historical prices are more concentrated around the mean. However, this also points to the fact that large fluctuations are probably concentrated in the tails. 
Table 2 - Statistical parameters for BelexLINE based on the daily values of index
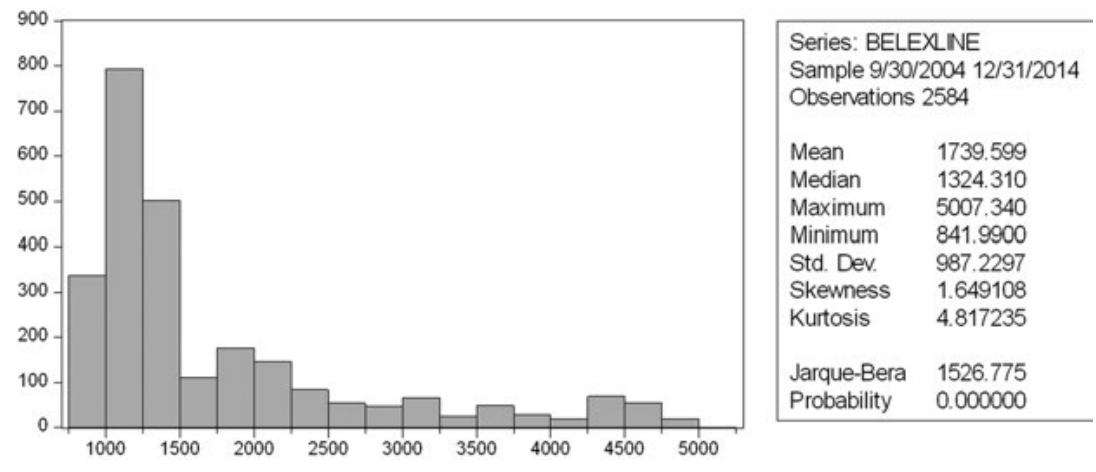

In addition, it is important to note that both indexes have Jarque-Bera test values high, which implies that distribution of residuals departs from normal distribution and therefore we reject null hypothesis that analyzed series is normally distributed.

In order to determine the existence of stationarity, augmented Dickey-Fuller's (DF) test was used. The actual values of the indexes were used during the testing of unit root. Also, it is important to note that Schwartz's information was used in the analysis and testing. As it can be seen from Table 3 the result of the augmented DF test for Belex 15 index indicates that the value of augmented DF test is greater than the critical value for $1 \%, 5 \%$ and $10 \%$ levels, which implies that the null hypothesis about the existence of a unit root should not be rejected. However, when differentiated data of the first order is tested, the value of DF test are lower than a critical value of $1 \%, 5 \%$ and $10 \%$ levels, indicating that it is necessary to reject the null hypothesis of the existence of a unit root and therefore accept alternative hypothesis on stationarity of time series.

On the other hand, testing of BelexLINE index also implies to the fact that the values of augmented DF test is more than critical values for the levels of $1 \%$, $5 \%$ and $10 \%$, which implies that it is necessary to accept null hypothesis about the existence of unit root (table 4). Results of augmented DF test when different data on the first level is used indicate that it is necessary to reject null hypothesis and accept alternative hypothesis about the existence of stationarity.

In order to determine the existence of no stationarity, the analysis of existence of correlation between residuals was conducted. For Belex15 index, correlogram shown in table 7 indicates that the result of augmented DF test cannot be accepted as correct taking into account that statistical significant coefficients of autocorrelation is shown in the ninth row.

On the other hand, the BelexLINE index shows that the first 30 movements do not have statistical significant coefficients of autocorrelation present, which points to the fact that the result of the augmented DF test for BELEXLine can be accepted as accurate. 
Table 3 -Results of Augmented test based on daily data on the level of Index Belex15 without the inclusion of trend

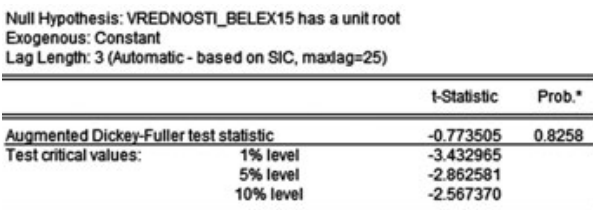

"Mackinnon (1996) one-sided p-values.

Augmented Dickey-Fuller Test Equation

Dependent Variable: D(VREDNOST_BELEX15)

Method: Least Squares

Date: 04/21/15 Time: 23:33

Sample (adjusted): 10/10/2005 12/31/2014

Included observations: 2327 after adjustments

\begin{tabular}{lrrrr}
\hline \multicolumn{1}{c}{ Variable } & Coefficient & Std. Error & t-Statistic & Prob. \\
\hline \hline VREDNOST_BELEX15(-1) & -0.000413 & 0.000534 & -0.773505 & 0.4393 \\
D(NREDNOST__BELEX15(-1)) & 0.389042 & 0.020556 & 18.92583 & 0.0000 \\
D(NREDNOST_BELEX15(-2)) & 0.004269 & 0.022084 & 0.193318 & 0.8467 \\
D(VREDNOST_BELEX15(-3)) & -0.136091 & 0.020559 & -6.619574 & 0.0000 \\
\multicolumn{1}{c}{ C } & 0.294002 & 0.641975 & 0.457965 & 0.6470 \\
\hline \hline R-squared & 0.160360 & Mean dependent var & -0.151547 \\
Adjusted R-squared & 0.158914 & S.D. dependent var & 19.37663 \\
S.E. of regression & 17.77046 & Akaike into criterion & 8.595098 \\
Sum squared resid & 7332622 & Schwarz criterion & 8.607458 \\
Log likelihood & -9995.396 & Hannan-Quinn criter. & 8.599602 \\
F-statistic & 110.8680 & Durbin-Watson stat & 1.998451 \\
Prob(F-statistic) & 0.000000 & & & \\
\hline \hline
\end{tabular}

Table 5 - Results of augmented test on the daily data on the level of index BelexLINE without trend included

\begin{tabular}{|c|c|c|c|c|}
\hline \multicolumn{5}{|c|}{ 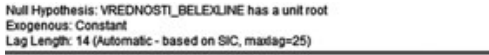 } \\
\hline & & & HStabste & Proo: \\
\hline Test crical values: & $\begin{array}{l}\text { atc } \\
15 \% \text { level } \\
5 \% \text { level } \\
10 \% \text { level }\end{array}$ & & $\begin{array}{l}-1.443430 \\
-3.432702 \\
-2862465 \\
-2567307 \\
\end{array}$ & 0.5623 \\
\hline \multicolumn{5}{|l|}{ "Wackiomnon (1996) one-sided p-values. } \\
\hline \multicolumn{5}{|c|}{ 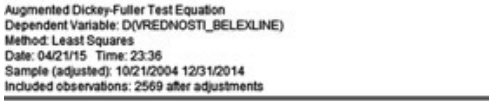 } \\
\hline Variable & Coefficient & SAd Erroe & LStabstic & Prob. \\
\hline \multirow{16}{*}{ 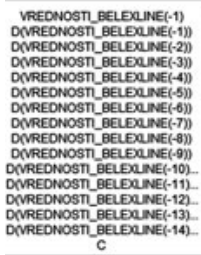 } & .0 .00 & 0,0 & -1.44 & \\
\hline & 0.36 & & & \\
\hline & 0.042167 & 0.020971 & & 0.045 \\
\hline & -0.0820933 & & -3955582 & 0.0001 \\
\hline & 0.019438 & 0.021028 & 0.924383 & 0.3554 \\
\hline & -0.002773 & 0.021002 & .0132052 & $0.895 a$ \\
\hline & 0.025566 & 0020966 & 1219403 & 0.2228 \\
\hline & 0.000510 & 0.020021 & 0.406757 & 0.6842 \\
\hline & 0.073564 & 0,020024 & 3515812 & 0.0004 \\
\hline & 0.062628 & 0.020969 & 2996282 & 0.0028 \\
\hline & 0.056145 & 0.021007 & 2672727 & 0.0076 \\
\hline & -0.013702 & 0.021032 & -0651466 & 0.5148 \\
\hline & -0.047603 & 0.020069 & -2270208 & 0.0233 \\
\hline & 0.044656 & 0020074 & 2129047 & 0.0333 \\
\hline & 0.101826 & 0.019594 & 5.170507 & 0.0000 \\
\hline & 0.991243 & 0.762278 & 1.300369 & 0.1936 \\
\hline \multirow{7}{*}{$\begin{array}{l}\text { R-squared } \\
\text { Agusted R-squared } \\
\text { SE, of regression } \\
\text { Sum squared resid } \\
\text { Log likelinood } \\
\text { F-stanstic } \\
\text { Prob(F-statistc) }\end{array}$} & & \multirow{7}{*}{\multicolumn{2}{|c|}{ 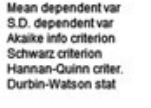 }} & \\
\hline & 0.200335 & & & 2127915 \\
\hline & 19.02066 & & & 8735979 \\
\hline & 924415.8 & & & 2772421 \\
\hline & -11205.36 & & & 8749191 \\
\hline & 43.89974 & & & 1.996907 \\
\hline & 0.000 & & & \\
\hline
\end{tabular}

Table 4 - Results of Augmented test based on differentiated daily data on the level of Index Belex15 without the inclusion of trend

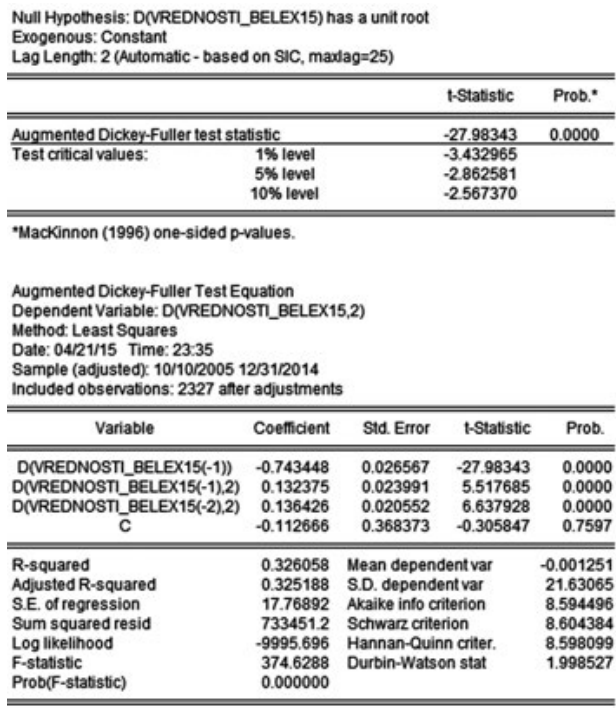

Table 6 - Results of augmented test on the differentiated daily data on the level of index BelexLINE without trend included

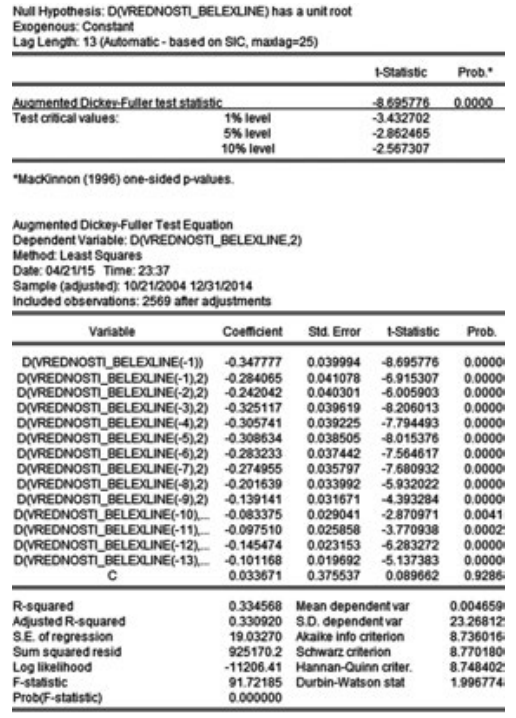


Table 7 - Correlogram of autocorrelation, partial autocorrelation and Q-statistic value for Belex15

\begin{tabular}{|c|c|c|c|c|c|c|}
\hline Autocorrelation & Partial Correlation & & AC & PAC & Q-Stat & Prob \\
\hline 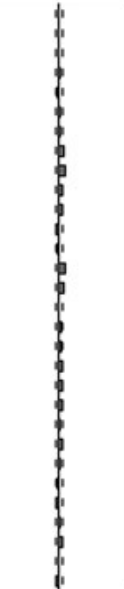 & 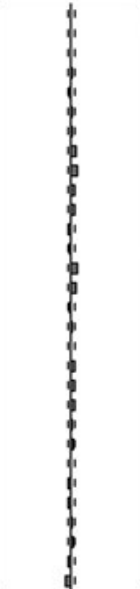 & $\begin{array}{r}1 \\
2 \\
3 \\
4 \\
5 \\
6 \\
7 \\
8 \\
9 \\
10 \\
11 \\
12 \\
13 \\
14 \\
15 \\
16 \\
17 \\
18 \\
19 \\
20 \\
21 \\
22 \\
23 \\
24 \\
25 \\
26 \\
27 \\
28 \\
29 \\
30\end{array}$ & $\begin{array}{r}0.001 \\
-0.002 \\
0.001 \\
0.018 \\
-0.010 \\
0.022 \\
0.009 \\
0.074 \\
0.091 \\
0.057 \\
0.043 \\
-0.027 \\
-0.018 \\
0.093 \\
0.069 \\
-0.006 \\
0.030 \\
0.026 \\
0.059 \\
0.049 \\
0.061 \\
0.019 \\
0.047 \\
0.012 \\
-0.022 \\
-0.039 \\
0.018 \\
0.064 \\
-0.006 \\
-0.048\end{array}$ & $\begin{array}{r}0.001 \\
-0.002 \\
0.001 \\
0.018 \\
-0.010 \\
0.022 \\
0.009 \\
0.074 \\
0.092 \\
0.058 \\
0.045 \\
-0.029 \\
-0.020 \\
0.090 \\
0.067 \\
-0.010 \\
0.015 \\
0.007 \\
0.046 \\
0.045 \\
0.065 \\
0.014 \\
0.027 \\
-0.005 \\
-0.041 \\
-0.047 \\
0.010 \\
0.041 \\
-0.040 \\
-0.077\end{array}$ & $\begin{array}{l}0.0013 \\
0.0135 \\
0.0164 \\
0.7884 \\
1.0032 \\
2.0973 \\
2.2881 \\
15.209 \\
34.731 \\
42.290 \\
46.538 \\
48.267 \\
49.010 \\
69.117 \\
80.282 \\
80.354 \\
82.486 \\
84.058 \\
92.145 \\
97.677 \\
106.55 \\
107.36 \\
112.53 \\
112.88 \\
114.05 \\
117.59 \\
118.36 \\
128.07 \\
128.15 \\
133.67\end{array}$ & $\begin{array}{l}0.971 \\
0.993 \\
0.999 \\
0.940 \\
0.962 \\
0.911 \\
0.942 \\
0.055 \\
0.000 \\
0.000 \\
0.000 \\
0.000 \\
0.000 \\
0.000 \\
0.000 \\
0.000 \\
0.000 \\
0.000 \\
0.000 \\
0.000 \\
0.000 \\
0.000 \\
0.000 \\
0.000 \\
0.000 \\
0.000 \\
0.000 \\
0.000 \\
0.000 \\
0.000\end{array}$ \\
\hline
\end{tabular}

Table 8 - Correlogram of autocorrelation, partial autocorrelation and Q-statistic value for BelexLINE

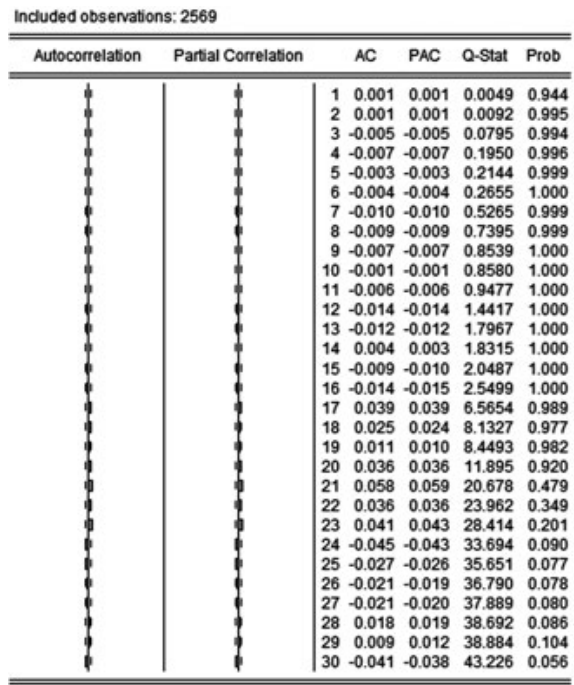

\section{Conclusion}

Taking into account that the results of testing of two most prominent indexes on Belgrade Stock Exchange, Belex15 and BelexLINE, differ depending on the fact if first order data was used or not, we can conclude that the conditions necessary for the presence of a weak form market efficiency are not fully met. Testing of weak form of market efficiency was conducted based on the standard tests of unit root and autocorrelation. Augmented Dickey-Fuller test was used in order to examine the no stationarity of time series of data which is in accordance with the random walk hypothesis. On the other hand, Box-Pierce and Ljung-Box test were used for determination of the degree of correlation, with the aim of determining the presence of weak for market efficiency. ${ }^{12}$

This was to some extent possible to conclude based on the characteristics of the capital market in Serbia. More precisely, very shallow and underdeveloped market affects the insufficient number of participants, primarily institutional investors. Consequently, the capital market is not sufficiently transparent and thus allows certain investors to capitalize on irregularities which occur on the capital market in Serbia. The empirical results presented in this paper indicate a lack of weak form market efficiency and consequently the additional regulatory reforms are necessary in order to eradicate inefficiencies of the market.

12 Ljung, Greta M. and George E. P. Box (1978):“On a Measure of Lack of Fit in Time Series Models", Biometrika, 65(2): 297-303. 


\section{Literature}

- Fama, Eugene F. and Kenneth R. French, (1988): "Permanent and Temporary Components of Stock Prices", Journal of Political Economy, 96(2), 246-273.

- Lo, Andrew W. and Craig A. MacKinlay, (1988): "Stock Market Prices do not Follow Random Walks: Evidence from a Simple SpecificationTest”, Review of Financial Studies, 1(1), 41-66.

- Fama, Eugene F. (1970): "Efficient Capital Markets: A Review of Theory and Empirical Work", Journal of Finance, 25(2), 383-417

- Chan, Kam C., Benton E. Gup i Ming-Shiun Pan, (1997), "International Stock Market Efficiency and Integration: A Study of Eighteen Nations", Journal of Business Finance \& Accounting, 24(6), 803-813.

- Bekaert, Geert and Robert J. Hodrick, (1992): "Characterizing Predictable Components in Excess Returns on Equity and Foreign Exchange Markets", Journal of Finance, 47(2), 467-509.

- Worthington, A. C. and Higgs, H. (2005): "Weak-Form Market Efficiency in Asian Emerging and Developed Equity Markets: Comparative Tests of Random Walk Behavior", Working Paper 3, School of Accounting \& Finance, University of Wollongong

- Claessens Stijn, Susmita Dasgupta i Jack Glen, (1995): "Return Behavior in Emerging Stock Market", The World Bank Economic Review, 9(1): 131-151.

- Gilmore, Claire G. and Ginette M. McManus (2003): "Random-Walk and Efficiency Tests of Central European Equity Markets", Managerial Finance, 29(4), 42-61.

- Mateus, Tiago (2004): "The risk and predictability of equity returns of the EU accession countries", Emerging Markets Review, 5(2), 241-266.

- Belgrade Stock Exchange. Retrieved at www.belex.rs

- Working, Holbrook, (1934): "A Random Difference Series for Use in the Analysis of Time Series", Journal of the American Statistical Association, 29(185), 11-24.

- Malkiel, Burton G., (1973): A Random Walk Down Wall Street, New York, NY: W. W. Norton \& Company.

- $\quad$ Ljung, Greta M. and George E. P. Box, (1978): “On a Measure of Lack of Fit in Time Series Models”, Biometrika, 65(2), 297-303. 
JOVANA KRŠIKAPA-RAŠAJSKI, MS

Menadžer, Raiffeisen Banka, Beograd

Prof. DR Siniša G. RANKov

profesor u penziji Fakulteta za kompjuterske nauke,

Univerzitet „Džon Nezbit”, Beograd

\section{TESTIRANJE SLABE FORME EFIKASNOSTI NA TRŽIŠTU KAPITALA U SRBIJI}

Slaba forma hipoteze efikasnosti tržišta kapitala pretpostavlja da učesnici na finansijskim tržištima nisu u mogućnosti da ostvare iznadprosečne prinose na osnovu istorijskih cena. Da bi se utvrdila prisutnost slabe forme efikasnosti tržišta na srpskom tržištu, u analizu su uzeti dnevni podaci o kretanju dva najznačajnija indeksa Beogradske berze BELEX 15 i BELEX LINE, od njhovog osnivanja do 31 decembra 2014. godine. Rezultati dobijeni analizom i testiranjem ukazuju na činjenicu da se tržište kapitala u Srbiji ne može smatrati dovoljno efikasnim, tačnije da postulati podrazumevani slabom formom tržišne efikasnosti nisu u potpunosti ispunjeni. Uzimajući u obzir da je tržište kapitala u Srbiji još uvek nedovoljno razvijeno, prvenstveno zbog malih obima, prometa i vrsta hartija od vrednosti kojima se trguje na tržištu kao i činjenice da nije dovoljno uredjeno i transparentno, na istom je prisutan nedostatak investitora. Shodno svemu tome, analize prezentovane u ovom radu ukazuju na slabu održivost hipoteze o efikasnosti tržišta u Srbiji.

Ključne reči: Slaba forma hipoteze efikasnosti tržišta kapitala, finansijska tržišta, Beogradska berza, BELEX 15 indeks, BELEX LINE indeks, Polu-jaka forma efikasnosti, Jaka forma efikasnosti finansijskih tržišta 